\title{
MALLOMONAS CRONBERGIAE (CHRYSOPHYCEAE, STRAMENOPILES), A NEW SPECIES FROM THE GUINEO-CONGOLIAN RAINFOREST IN CAMEROON
}

\author{
Jolanta PiąteK ${ }^{1} \&$ Magdalena LuKaszek
}

\begin{abstract}
A new species of Mallomonas Perty, M. cronbergiae J. Piątek sp. nov., was found in a tropical shallow stream pool in the Guineo-Congolian rainforest in Cameroon. It belongs to the series Ouradiotae and is similar to the three other Mallomonas taxa from this series, namely M. ouradion Harris \& Bradley, M. parvula Dürrschmidt and M. parvula var. nichollsii Wujek \& Bland, but differs in some morphological characters that clearly differentiate $M$. cronbergiae as a distinct species. The new species has a different size of scales, characteristic 3-7 pores at the posterior rim, an anterior flange ornamented with papillae, and a shield thickly ornamented with papillae (14-16 per scale width). The species is described and illustrated with the use of light and scanning electron microscopy.
\end{abstract}

Key words: Africa, Cameroon, Chrysophyceae, Mallomonas, new species, scale morphology

Jolanta Piątek \& Magdalena Lukaszek, Department of Phycology, W. Szafer Institute of Botany, Polish Academy of Sciences, Lubicz 46,31-512 Kraków,Poland; e-mail: j.piatek@botany.pl,m.lukaszek@botany.pl

\section{INTRODUCTION}

The genus Mallomonas Perty (1852) comprises solitary, flagellated cells covered by silica scales and (sometimes) bristles. Its members usually occur in freshwater habitats. In electron microscopy the ultrastructure of Mallomonas scales and bristles proved to be a reliable taxonomical feature enabling distinction between species (Asmund \& Kristiansen 1986; Siver 1991). In this study we describe a new Mallomonas species from Cameroon, belonging to the series Ouradiotae Asmund \& Kristiansen (1986).

Previously only three taxa were included in the series: M. parvula Dürrschmidt (1982), M. parvula var. nichollsii Wujek \& Bland (1988) and M. ouradion Harris \& Bradley (1958). Despite the quite ubiquitous distribution of two of them (M. parvula, M. ouradion) (Kristiansen \& Preisig 2007) there was no record from Africa yet. One of them (M. parvula var. nichollsii) is known only from North America (Florida) (Wujek \& Bland 1988). Features that characterize the series are the

\footnotetext{
1 Corresponding author
}

absence of a dome and the presence of a broad V-rib. Additionally, the scales are ornamented with papillae and the secondary layer has a somewhat incomplete appearance (Kristiansen 2002).

\section{MATERIALS AND METHODS}

The materials were collected on 12 December 2007 from the edge of a shallow stream pool in the GuineoCongolian rainforest in the East Region of Cameroon (Fig. 1). Plankton water and sediment were taken with a pipette. The samples were fixed with Lugol's solution. Immediately after collection, water temperature $\left({ }^{\circ} \mathrm{C}\right)$ and conductivity $\left(\mu \mathrm{S} \cdot \mathrm{cm}^{-1}\right)$ were measured with a CC-102 conductivity meter (Elmetron IP67), and pH with a CP-103 waterproof pH-meter (Elmetron IP67).

The specimens were examined and identified using standard light and phase contrast microscopy (LM) and scanning electron microscopy (SEM). Slide preparations mounted in water were studied using a Nikon Eclipse 600 light microscope. Micrographs were taken with a Nikon DS-Fil camera. For SEM observations, each sample was pipetted onto clean cover glasses, air-dried, and affixed to an aluminum stub with double-sided transparent tape. The stubs were sputter-coated with carbon 

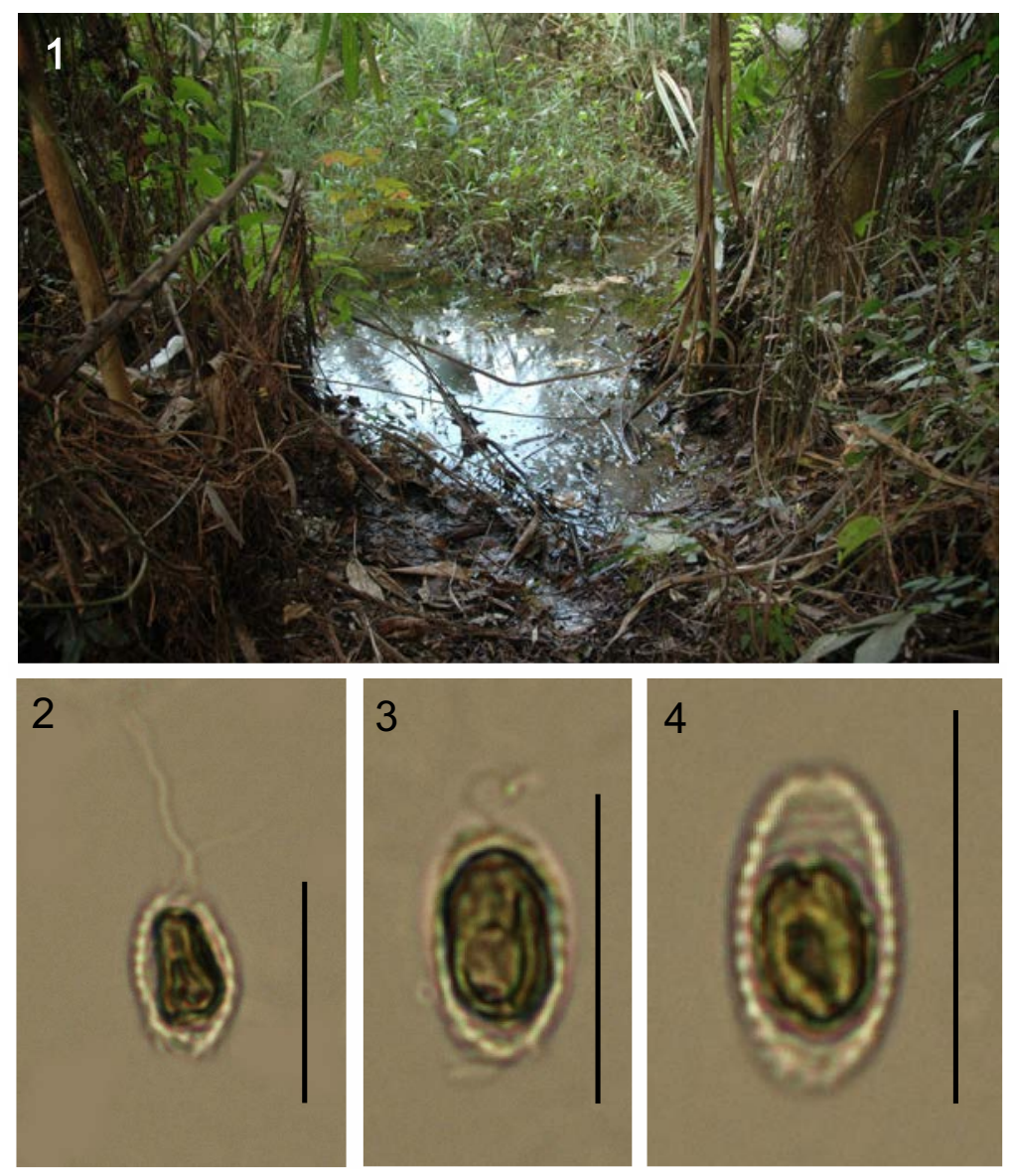

Figs 1-4. Mallomonas cronbergiae J. Piątek, sp. nov. 1 - Sampling site (type locality) - edge of stream pool in Guineo-Congolian rainforest (photo M. Piątek). 2-4 - Whole cells with scales and bristles seen by LM. Scale bars for LM $=20 \mu \mathrm{m}$.

using a Cressington sputter-coater and viewed with a Hitachi S-4700 field emission scanning electron microscope.

The description of the new Mallomonas species follows the terminology of Sivier (1991), Kristiansen (2002) and Kristiansen and Preisig (2007). All measurements were taken directly from the collected material, under LM for cells and from SEM micrographs for scales and other elements.

\section{RESULTS}

Mallomonas cronbergiae J. Piątek, sp. nov.

Figs 2-10

LM DESCRIPTION. Cells oval with bristles, with at least one chloroplast and two flagella. Cells 13.7-17.6 $\mu \mathrm{m}$ long and 8.6-9.6 $\mu \mathrm{m}$ wide.
SEM DESCRIPTION. Scales elliptical and symmetrical, 3.2-4.0 $\mu \mathrm{m}$ long and 2.0-2.3 $\mu \mathrm{m}$ wide. Posterior rim encircling half or almost half of scale perimeter. Well-developed V-rib separating shield from posterior flange. Shield covered with densely spaced, well-developed papillae. Papillae $0.07 \mu \mathrm{m}$ in diameter, 14-16 per scale width (counted where V-rib ends). Posterior flange smooth, with 3-7 pores/holes at base of posterior rim. Bristles smooth, short, thick, slightly curved, with bifurcated distal tip (sometimes not bifurcated), 3.5-5.8 $\mu \mathrm{m}$ long and $0.2-0.3 \mu \mathrm{m}$ wide. Stomatocysts not observed.

Type: CAMEROON, EASt Region, Department of Lom-et-Djérem: between Boni and Kagama, $c a 10 \mathrm{~km}$ 

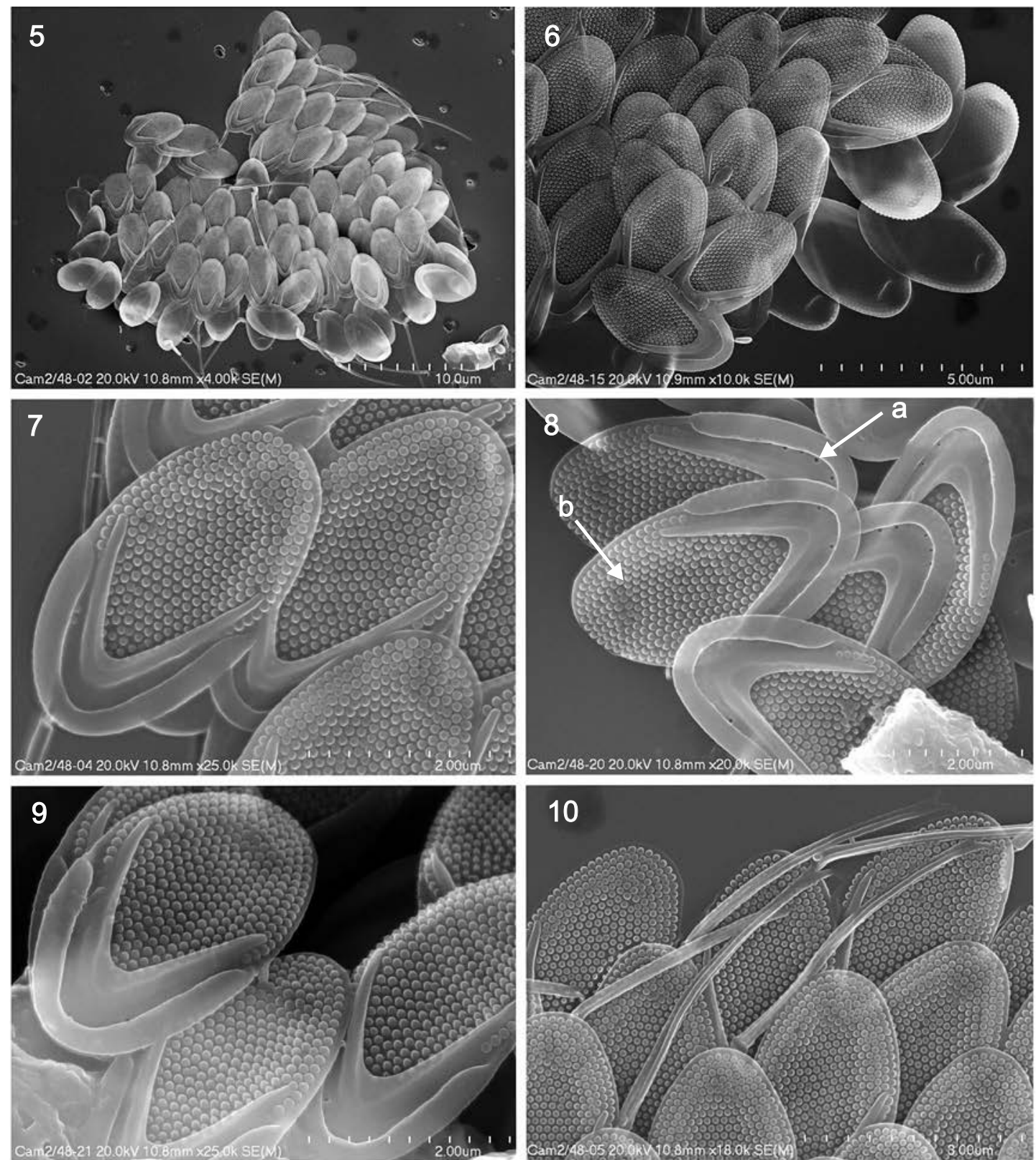

Figs 5-10. Mallomonas cronbergiae J. Piątek, sp. nov. seen by SEM. 5 - Scales covering the cells. 6-9 - Group of scales with characteristic markings: (a) scales have 3-7 pores/holes at base of posterior rim, (b) shield is thickly ornamented with papillae (14-16 per scale width, counted where V-rib ends); 8 - holotype. Individual diagnostic features are arrowed. 10 - Smooth, thick, slightly curved bristles with bifurcated distal tip.

SW of Bertoua, $04^{\circ} 30^{\prime} 38.2^{\prime \prime} \mathrm{N}, 13^{\circ} 36^{\prime} 53.5^{\prime \prime} \mathrm{E}$, elev. $c a$ 652 m a.s.1., 12 December 2007, leg. J. Piatek (HOLOTYPE: Fig. 8).
ETymology. The species is named in honor of the eminent phycologist Professor Gertrud Cronberg, who, among other studies, worked on the 


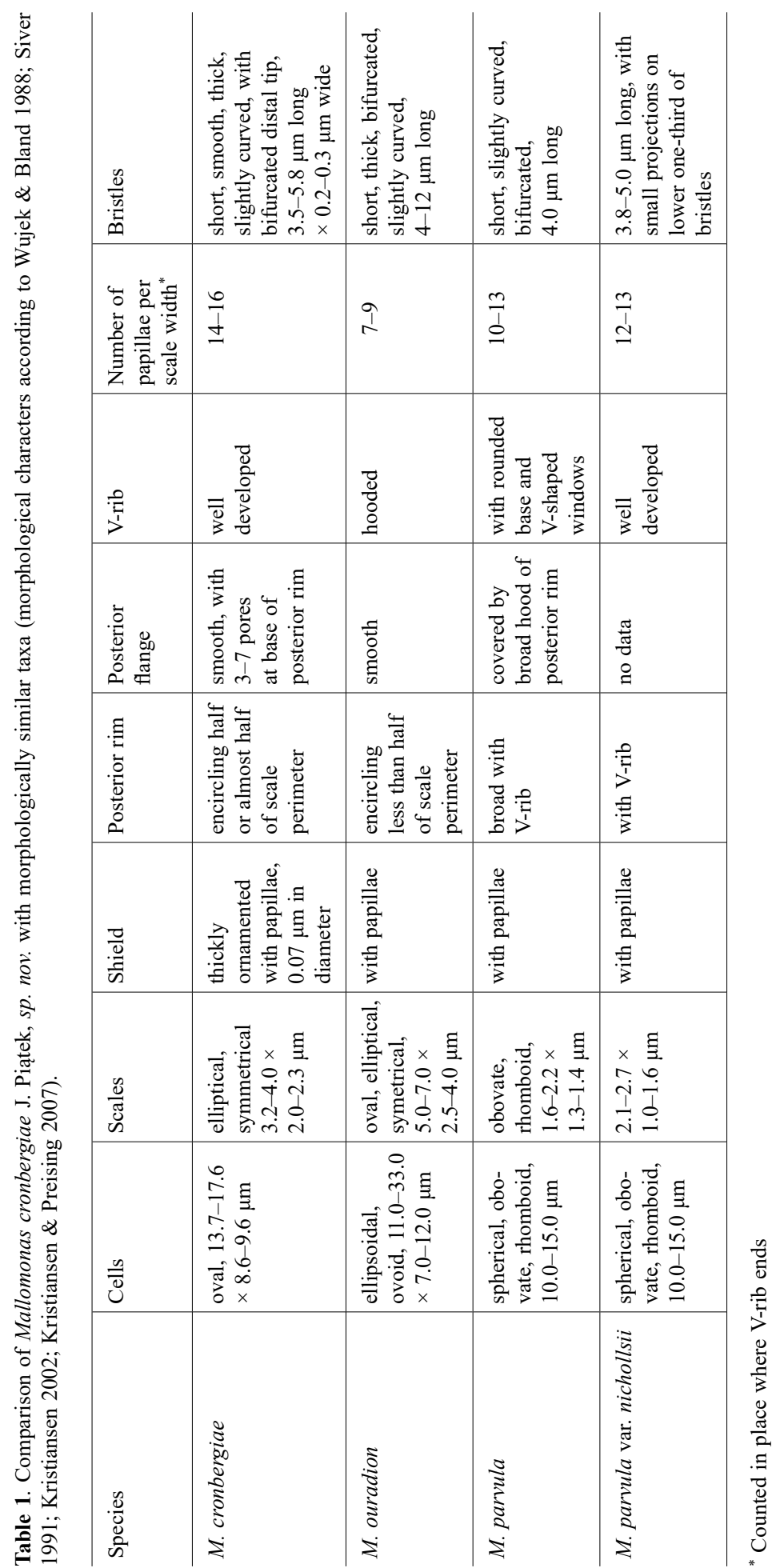


chrysophytes of the Tropics and published several papers on this group of algae.

Distribution. This new Mallomonas species is known only from the type locality in Cameroon.

Haвitat. The sample was collected in a semishaded place in rainforest from the edge of a shallow stream pool rich in decaying leaf litter (Fig. 1). The water was black, with temperature $24^{\circ} \mathrm{C}$, conductivity $24 \mu \mathrm{S} \cdot \mathrm{cm}^{-1}$ and $\mathrm{pH}$ 6.39. The species co-occurred with other algae, especially with many different specimens of Cyanophyta and Bacillariophyceae, and single specimens of Euglenophyta.

Notes. Mallomonas cronbergiae has several unique morphological features that justify its description as a new species: size of scales (3.2-4.0 $\times 2.0-2.3 \mu \mathrm{m}), 3-7$ pores at posterior rim, anterior flange ornamented with papillae, and shield thickly ornamented with papillae (14-16 per scale width). This species is assigned to series Ouradiotae and is similar to the three other taxa from this series, which are contrasted and discussed below (Table 1).

\section{Discussion}

Mallomonas ouradion differs from $M$. cronbergiae in having almost twice larger scales $(5 .-7 . \times 2.5-$ $4.0 \mu \mathrm{m}$ - Siver 1991; Kristiansen 2002; Kristiansen \& Preisig 2007). Moreover, M. ouradion has $c a$ 7-9 papillae per scale width (counted where V-rib ends), whereas $M$. cronbergiae has 14-16 papillae. It is striking that $M$. cronbergiae has twice smaller scales, with more papillae per scale width than $M$. ouradion. Additionally, $M$. cronbergiae differs from the latter species in having 3-7 pores/holes located at the base of the posterior rim (they are absent in M. ouradion).

Mallomonas parvula and M. parvula var. nichollsii differ in having spherical cells and smaller scales, $1.3-1.4 \times 1.6-2.2 \mu \mathrm{m}$ (Wujek \& Bland 1988; Siver 1991; Kristiansen 2002; Kristiansen $\&$ Preisig 2007). The cells of $M$. cronbergiae are oval and the scales are more than twice longer than in the latter species. The number of papillae per scale width is another characteristic differentiating the three taxa: 10-13 papillae in M. parvula and 12-13 papillae in M. parvula var. nichollsii, versus 14-16 papillae in $M$. cronbergiae. Furthermore, the latter species has 3-7 pores/holes located at the base of the posterior rim, features absent in M. parvula and M. parvula var. nichollsii.

Recently another new species was found in the materials from Cameroon: M. camerunensis J. Piątek (2015), which belongs to the series Papillosa Asmund \& Kristiansen (1986). As pointed out by Němcová and Kreidlová (2013), even though records of new Mallomonas species are continuously published, it seems that the number of species and their distribution may be underestimated.

Acknowledgements. We thank Professor Dominique C. Mossebo (Yaoundé, Cameroon) for facilitating our application for a research permit, Anna Latkiewicz (Kraków, Poland) for her assistance with the SEM images, Marcin Piątek (Kraków, Poland) for the photograph of the type locality, and the anonymous reviewers for their constructive suggestions. This work was funded in part by the W. Szafer Foundation for Polish Botany and statutory funds of the W. Szafer Institute of Botany, Polish Academy of Sciences, Kraków, Poland.

\section{REFERENCES}

Asmund B. \& Kristiansen J. 1986. The genus Mallomonas (Chrysophyceae). A taxonomic survey based on the ultrastructure of silica scales and bristles. Opera Bot. 85: 1-128.

DüRRSCHMIDT M. 1982. Mallomonas parvula sp. nov. and Mallomonas retifera $\mathrm{sp}$. nov. (Chrysophyceae, Synurophyceae) from South Chile. Canad. J. Bot. 60: 651-656.

Harris K. \& Bradley D. E. 1958. Some unusual Chrysophyceae studied in the electron microscope. Journal of General Microbiology 18: 71-83.

KRISTIANSEN J. 2002. The genus Mallomonas (Synurophyceae). A taxonomic survey based on the ultrastructure of silica scales and bristles. Opera Bot. 139: 1-218.

Kristiansen J. \& Preisig H. R. 2007. Chrysophyte and haptophyte algae. 2(2). Synurophyceae. Spektrum Akademischer Verlag, Berlin.

NĚMcová Y. \& Kreidloví J. 2013. Two new species of Mallomonas (Chrysophyceae: Synurales): Mallomonas temonis and Mallomonas divida. Phytotaxa 87(1): 11-18.

Perty M. 1852. Zur Kenntniss kleinster Lebensformen: nach Bau, Funktionen, Systematik, mit Specialverzeichniss der in der Schweiz beobachteten. Verlag von Jent \& Reinert, Bern. 
PiąteK J. 2015. Mallomonas camerunensis sp. nov. (Chrysophyceae, Stramenopiles) from a shallow puddle in the Guineo-Congolian rainforest in Cameroon. Polish Bot. J. 60: 119-126.

Siver P. A. 1991. The biology of Mallomonas. Morphology,
Taxonomy and Ecology. Developm. Hydrobiologia 63: $1-230$.

Wujek D. E. \& Bland R. G. 1988. Spiniferomonas and Mallomonas: Descriptions of two new taxa of Chrysophyceae. Trans. Amer. Microscop. Soc. 107: 301-304. 